\title{
Issues affecting British honey bee biodiversity and the need for conservation of this important ecological component
}

\author{
*A. G. S. Cuthbertson; M. A. Brown \\ The Food and Environment Research Agency, National Bee Unit, Sand Hutton, York YO41 1LZ, UK \\ Received 8 September 2008; $\quad$ revised 2 June 2009; accepted 6 August 2009; $\quad$ available online 1 September 2009
}

\section{INTRODUCTION}

Bees are the dominant and most specialised pollinators of the world's quarter million angiosperms (Buchmann and Ascher, 2005). Both generalist and specialist bees harvest vast amounts of pollen for their brood, moving grains from flower to flower, thus, greatly effecting pollination (Buchmann and Nabhan, 1997). Although, it is the wind-pollinated grain and cereal crops that keep the worlds six billion humans from starvation, healthy human diets would lack the tasty and nutritious fruits, seeds, vegetables and some nuts if it were not for bee pollination (Buchmann and Nabhan, 1997). Fruits and seeds also provide many by products (fibres, oils, beverages, botanicals and medicines) that humans need, while also feeding many of the world's mammals, birds and some reptiles. Pollination by bees is obvious (Free, 1964), but ecologists, economists and others often forget the important ecological role played by bees. Within the United Kingdom (UK) recent estimates suggest that for both horticultural and agricultural crops grown commercially that benefit from bee pollination are in the region of $£ 200$ million per annum (Carreck and Williams, 1998; Temple et al., 2001; Wilkins et al., 2007). Many important UK horticultural crops, such as apples, may cease to be economically viable if it were not for honey bee pollination (Cuthbertson and Brown, 2006a). The overall value of bees, in general, to wild plant pollination is without doubt substantial, but impossible to evaluate in economic terms because the pollination requirements of most of the nearly 1800 species of wild plant in the British Isles are unknown. The millennium ecosystem assessment project estimates the global

$\triangle$ *Corresponding Author Email: andrew.cuthbertson@fera.gsi.gov.uk Tel.: +44 (0) 1904 462201; Fax: +44 (0) 1904462111 annual monetary value of pollination to be in the order of many hundreds of billions of dollars (MEA. 2005). Natural and anthropogenic threats to bees are not unique, as these include familiar causes of biodiversity losses in other animals and plants. Fragmentation of landscapes into habitat islands, conversion of wildlands for human uses (agriculture, housing, roadways, mining, etc.) impact bee populations by eliminating nesting sites and decreasing floral resources and nesting materials. Since most of the worlds bees are ground nesting, urbanization covers over prime bee habitat. Some species can survive, even prosper in human-altered landscapes, but housing developments eliminate many bee species due to loss of their nest sites and floral hosts. The production of roadways pose hidden threats as killing lanes, probably killing many bees and other pollinators annually. However, run-off from roadsides, often rich in nitrates, can result in profuse bloom of many flowers visited by bees.

\section{Pesticides and non-target species}

Many crops that require insect pollination, for example apple orchards, also have active pest management programmes that include the use of insecticidal sprays (Cuthbertson and Murchie, 2003; Cuthbertson et al., 2003; Cuthbertson and Brown, 2006a; Cuthbertson and Murchie, 2006a,b). The timing of these sprays is critical as often non-target species can be severely affected by the application of chemical pesticides (Cuthbertson, 2004). The application of chemical sprays needs to be undertaken either prior to the bees being moved onto the crop or immediately after their removal. Under pressure of timely application 
of insecticide sprays, fruit growers often use methods and materials that endanger bees. Bees also do not recognize fence lines and therefore one grower spraying his crops may have devastating effects on bee colonies in neighbouring fields. Insecticides do vary in toxicity towards bees. However, most induce mortality or sublethal effects for foraging bees. Herbicides eliminate weed species which may be important sources of pollen and nectar for native and managed bees. It is important for the beekeeper-pollinator to recognize potential hazards of managing bees on crops needing pollination. By understanding the growers problems may help the beekeeper anticipate insecticide use and make plans to avoid bee losses. Timely notification of intent to spray by the grower should form an important part of any pollination contract agreed. However, the introduction of managed and feral European honey bees (Apis mellifera; Fig. 1) into landscapes, such as apple orchards (Fig. 2), for pollination purposes can also have detrimental effects, for example, impact on native bees and other pollinators and wildlife through scramble competition for floral resources and nest sites. Honey bee pollinated flowers may also produce different sized seeds or lower quality seeds than native specialist bees on wildflowers. Therefore, it results in differing qualities of food resources for other insect and animal species. This can all have a negative knock-on effect on wildlife biodiversity.

Invasive plants (especially grasses) eliminate bare ground, choke out food plants and carry fires often in areas that have never been burnt. Many bee species, including rare ones, prefer early successional and other sparsely vegetated habitats, including waste areas and sand barrens that may not be perceived as valuable wildlife habitats by those focused on protecting vertebrates. Thus, it is important that landuse managers recognise all areas as potential bee habitats rather than eyesores in need of revegetation.

\section{Invertebrate pests and diseases}

Within the UK, there are also various species of invertebrate plant pests that are notifiable and subjected to a policy of eradication if found on propagators premises (Cuthbertson, 2005; Cuthbertson et al., 2009). These pests include: the South American leafminer (Liriomyza huidobrensis), thrips (Thrips palmi) and the sweetpotato whitefly (Bemisia tabaci). These nonindigenous species can cause severe damage to plant material and in some cases transmit numerous plant viruses, many of which are also non-indigenous to the UK (Cheek et al., 1994). Due to the UK's geographic island location it has been granted 'Protective Zone' status within the European Union (EU) against several of these invertebrate plant pest species (e.g. Bemisia tabaci). Therefore, it is highly desirable to keep these individual species out off the country, or if they are located, to have strategies for the containment and/or eradication of them in place to apply straight away (Cuthbertson and Walters, 2005; Cuthbertson et al., 2007, 2009). It is thought that many of these exotic pests have been transported round the world by the increased world trade in plants and plant products. Similarly, the mass movement and international trade of bees around the world could also transport and spread the incidence of pests and diseases. A prime

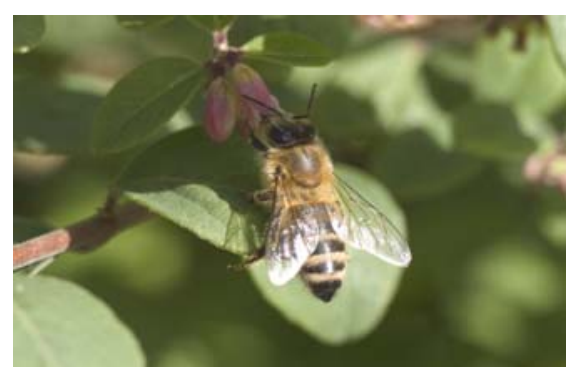

Fig. 1: The honey bee, Apis mellifera

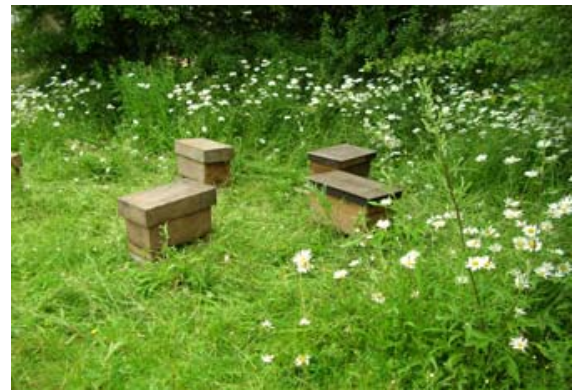

Fig. 2: Bee hives located near apple orchard to aid pollination

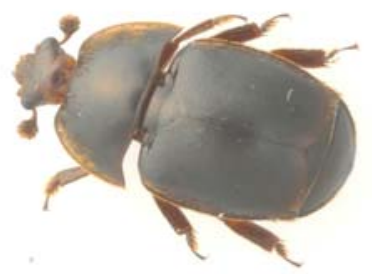

Fig. 3: The small hive beetle, Aethina tumida 
example of this is the small hive beetle, Aethina tumida Murray (Fig. 3), also a notifiable pest within the UK and European Union (Commission Decision 2003/881/ EC). These beetles, native to sub-Saharan Africa, are scavengers in colonies of African subspecies of honey bees (Elzen et al., 2001; Neumann and Elzen, 2004). Due to their presumed lack of economic importance in their native range, the beetles remained relatively unstudied prior to 1940 . However, the beetles have recently gained considerable international attention since they escaped their endemic range in the mid1990s, being first found in the United States in 1998 (Elzen et al., 1999). The main reason for this heightened attention is the beetles' ability to cause substantial damage to colonies of European races of honey bees (Hood, 2000; Ellis et al., 2003; Neumann and Elzen, 2004; Spiewok et al., 2007). With the recent discovery in 2005 of small hive beetle larvae in a consignment of queens imported illegally from Texas into Portugal (Murilhas, 2005), awareness throughout the EU of the potential threat of exotic incursions must be heightened. The potential cost from an accidental exotic incursion into the UK could be astronomical (Brown et al., 2002). For example, it has been estimated that in New Zealand the additional costs caused by the introduction of varroa into the country may well reach \$400-900 million over the next 35 years (Goodwin and Van Eaton, 1999). A similar situation also occurred in California during the spring of 2005 where, due to the effects of varroa, a dearth of available colonies for pollination of almonds required substantial imports of honey bees from Australia to make up the shortfall (Harrison, 2005; Lumpkin, 2005). A pest or disease outbreak within the UK could also lead to high colony losses and create a vacuum of available pollinators for important commercial farm crops (Cuthbertson and Brown, 2006a). The UK National Bee Unit field inspection team monitors for both $A$. tumida and Tropilaelaps spp now as part of a routine surveillance programme for exotic threats (Wilkins et al., 2007). Todate, no small hive beetles have been recorded within the UK (Cuthbertson et al., 2008).

Honey bees are also affected by a range of diseases (Wilkins et al., 2007), with two of the most serious being bacterial diseases that affect the developing brood. These are American foulbrood (AFB) and European foulbrood (EFB) (Morse and Flottum, 1997). The names of American foulbrood and European foulbrood do not relate to their distribution, but to where the first scientific investigations were carried out on the diseases. Both diseases have a wide geographical distribution, either one or both being found in most areas where bees are managed. The causative agent of AFB is the spore forming bacterium Paenibacillus larvae subsp. larvae (formerly known as Bacillus larvae) (Bailey and Ball, 1991; Faucon, 2004; Lindstrom and Fries, 2005). EFB is caused by the bacterium Melissococcus plutonius (formerly known as Melissococcus pluton). Both diseases are serious economic threats to beekeeping. AFB if left unchecked will always lead to the death of the infected colony, as a result, the UK operates an inspection/eradication policy (Wilkins et al., 2007). $\mathrm{EFB}$, on the other hand, is sometimes referred to as a stress disease. Colonies displaying signs of EFB, if left untreated may show signs of complete recovery and the disease signs disappear, however, if the colony is put under stress, the clinical signs of the disease reappear (Tomkies et al., 2009). Inevitably, the productivity of these infected hives will be affected. Both diseases are readily transmissible, the primary source of spread being the beekeeper, either due to contaminated equipment or the transfer of frames from infected colonies to healthy colonies. However, infected weak or dead colonies also act as a source of infection when robbed out by other bees. It is therefore important that in areas where these diseases occur suitable methods of control are in place to deal with outbreaks.

\section{CONCLUSION}

The Bee Health Programme for England and Wales, managed by the National Bee Unit, is funded to safeguard both honey bee populations and bee biodiversity in general, due to their importance in the pollination of both commercial crops and wild plants. The programme of research and development aims to provide up to date technical support to beekeepers. The work includes disease and pest diagnosis, development of contingency plans for emerging threats, import risk analysis and consultancy services to both government and industry. With continued research, education and good management of bee related habitats the biodiversity of this important pollinator group within the whole of the UK will remain well preserved for generations to come (Cuthbertson and Brown, 2006b; Wilkins et al., 2007). 


\section{ACKNOWLEDGEMENTS}

The authors are grateful to Mr. David Crossley, Fera photography department, for supplying the photographs.

\section{REFERENCES}

Bailey, L.; Ball, B. V., (1991). Honey bee pathology second edition. Academic Press Limited, London.

Brown, M. A.; Thompson, H. M.; Bew, M. H., (2002). Risks to UK beekeeping from the parasite mite Tropilaelaps clareae and the small hive beetle, Aethina tumida. Bee World, 83 (4), 151-164 (14 pages).

Buchmann, S. L.; Ascher, J. S., (2005). The plight of pollinating bees. Bee World, 86 (3), 71-74 (4 pages).

Buchmann, S. L.; Nabhan, G. P., (1997). The forgotten pollinators. Island Press, Washington DC, USA.

Carreck, N.; Williams, I., (1998). The economic value of bees in the UK. Bee World, 79 (3), 115-123 (9 pages).

Cheek, S.; Head, J.; Malumphy, C., (1994). Bemisia tabaci. Plant Pest Notice no. 17. Ministry of Agriculture, Fisheries and Food, London, UK (4 pages).

Cuthbertson, A. G. S., (2004). Unnecessary pesticide applications in Northern Ireland apple orchards due to misidentification of a beneficial mite species. Res. J. Chem. Environ., 8 (3), 77-78 (2 pages).

Cuthbertson, A. G. S., (2005). Protecting the UK from alien pests. Bio. News, 32 (1), 9 (1 page).

Cuthbertson, A. G. S.; Brown, M. A., (2006a). Vital pollinators: honey bees in apple orchards. Biologist, 53 (2), 78-81 (4 pages).

Cuthbertson, A. G. S.; Brown, M. A., (2006b). The value of the honey bee and the need for it to be protected. Bio. News, 35 (1), 14-15 (2 pages).

Cuthbertson, A. G. S.; Murchie, A. K., (2003). The impact of fungicides to control apple scab (Venturia inaequalis) on the predatory mite Anystis baccarum and its prey Aculus schlechtendali (apple rust mite) in Northern Ireland Bramley orchards. Crop Prot., 22 (9), 1125-1130 (6 pages).

Cuthbertson, A. G. S.; Murchie, A. K., (2006a). Environmental monitoring of economically important invertebrate pests in Bramley apple orchards in Northern Ireland. Int. J. Environ. Sci. Tech., 3(1), 1-7 (7 pages).

Cuthbertson, A. G. S.; Murchie, A. K., (2006b). The environmental impact of an orchard winter wash and early season pesticide applications on both a beneficial and a pest mite species in Bramley apple orchards. Int. J. Environ. Sci. Tech., 3 (4), 333-339 (7 pages).

Cuthbertson, A. G. S.; Walters, K. F. A., (2005). Pathogenicity of the entomopathogenic fungus, Lecanicillium muscarium, against sweetpotato whitefly Bemisia tabaci under laboratory and glasshouse conditions. Mycopathologia, 160 (4), 315-319 (5 pages).

Cuthbertson, A. G. S.; Fleming, C. C.; Murchie, A. K., (2003). Detection of Rhopalosiphum insertum (apple-grass aphid) predation by the predatory mite Anystis baccarum using molecular gut analysis. Agric. Forest Entomol., 5 (3), 219225 (7 pages).

Cuthbertson, A. G. S.; Walters, K. F. A.; Northing, P.; Luo, W., (2007). Efficacy of the entomopathogenic nematode,
Steinernema feltiae, against sweetpotato whitefly Bemisia tabaci (Homoptera: Aleyrodidae) under laboratory and glasshouse conditions. Bull. Ent. Res., 97 (1), 9-14 (6 pages).

Cuthbertson, A. G. S.; Mathers, J. J.; Blackburn, L. F.; Wakefield, M. E.; Collins, L. E.; Luo, W.; Brown, M. A., (2008). Maintaining Aethina tumida (Coleoptera: Nitidulidae) under quarantine laboratory conditions in the UK and preliminary observations on its behaviour. J. Apicult. Res., 47 (3), 192193 (2 pages).

Cuthbertson, A. G. S.; Blackburn, L.F.; Northing, P.; Mathers, J. J.; Luo, W.; Walters, K. F. A., (2009). Environmental evaluation of hot water treatments to control Liriomyza huidobrensis infesting plant material in transit. Int. J. Environ. Sci. Tech., 6 (2), 167-174 (8 pages).

Ellis, J. D.; Hepburn, H. R.; Delaplane, K.S.; Elzen, P. J., (2003). The effects of adult small hive beetles, Aethina tumida (Coleoptera: Nitidulidae), on nests and flight activity of Cape and European honey bees (Apis mellifera). Apidologie, 34 (4), 399-408 (10 pages).

Elzen, P. J.; Baxter, J. R.; Westervelt, D.; Randall, C.; Delaplane, K.S.; Cutts, L.; Wilson, W.T., (1999). Field control and biology studies of a new pest species, Aethina tumida Murray (Coleoptera: Nitidulidae), attacking European honey bees in the Western Hemisphere. Apidologie, 30 (5), 361-366 (6 pages).

Elzen, P. J.; Baxter, J. R.; Neumann, P.; Solbrig, A.; Pirk, C.; Hepburn, H. R.; Westervelt, D.; Randall, C., (2001). Behaviour of African and European subspecies of Apis mellifera toward the small hive beetle, Aethina tumida. J. Apicult. Res., 40 (1), 40-41 (2 pages).

Faucon, J. P., (2004). La loque américaine. La santé de l'abeille 202, 264-297 (33 pages).

Free, J. B., (1964). Comparison of the importance of insect and wind pollination of apple trees. Nature, 201 (3), 726727 (2 pages).

Goodwin, M.; Van Eaton, C., (1999). Elimination of american foulbrood without the use of drugs: A practical manual for beekeepers. National Beekeepers' Association of New Zealand Inc.

Harrison, B., (2005). U.S. beekeepers make history with first Australian bee imports. Am. Bee J., 145 (5), 287-289 (3 pages).

Hood, M., (2000). Overview of the small hive beetle Aethina tumida in North America. Bee World, 81 (1), 129-137 (9 pages).

Lindstrom, A.; Fries, I., (2005). Sampling of adult bees for detection of American foulbrood (Paenibacillus larvae subsp. larvae) spores in honey bee (Apis mellifera) colonies. J. Agri. Res., 44 (2), 82-86 (4 pages).

Lumpkin, D., (2005). Overcoming obstacles during 2005 almond pollination. Am. Bee J., 145 (4), 290-294 (5 pages).

M.E.A. (2005). Millennium Ecosystem Assessment. Ecosystems and human well being: Biodiversity synthesis. World Resources Institute, Washington, DC.

Morse, R. A.; Flottum, K., (1997). Honey bee pests, Predators and diseases. The A.I. Root Company, Medina, Ohio, USA.

Murilhas, A., (2005). EurBee Newsletter No.2, April 2005. (1 page).

Neumann, P.; Elzen, P. J., (2004). The biology of the small hive beetle (Aethina tumida, Coleoptera: Nitidulidae): Gaps in our knowledge of an invasive species. Apidologie, 35 (3), 229-247 (18 pages). 
Spiewok, S.; Pettis, J. S.; Duncan, M.; Spooner-Hart, R.; Westervelt, D.; Neumann, P., (2007). Small hive beetle, Aethina tumida, populations I: Infestation levels of honeybee colonies, apiaries and regions. Apidologie, 38 (6), 595-605 (7 pages).

Temple, M. L.; Emmett, B. J.; Scott, P. E.; Crabb, R. J., (2001). Economic Policy Evaluation of DEFRA's Bee Health Programme, ADAS Consulting Ltd., Woodthorne, Wergs Road Wolverhampton WV6 8TQ. Report to Department for Environment, Food and Rural Affairs, London, UK.
Tomkies, V.; Flint, J.; Johnson, G.; Waite, R.; Wilkins, S.; Danks, C.; Watkins, M.; Cuthbertson, A. G. S.; Carpana, E.; Marris, G.; Brown, M. A., (2009). Development and validation of novel field test kits for European foulbrood. Apidologie, 40 (1), 63-72 (10 pages).

Wilkins, S.; Brown, M. A.; Cuthbertson, A. G. S., (2007). The incidence of honey bee pests and diseases in England and Wales. Pest Manag. Sci., 63 (11), 1062-1068 (8 pages).

\section{AUTHOR (S) BIOSKETCHES}

Cuthbertson, A. G. S., B.Sc., Ph.D., Senior entomologist at the Food and Environment Research Agency in York, England, UK. Email: andrew.cuthbertson@fera.gsi.gov.uk

Brown M. A., B.Sc., Head of the National Bee Unit at the Food and Environment Research Agency in York, England, UK. Email: mike.brown@fera.gsi.gov.uk 